\title{
ASSESSMENT OF NUTRITION STATUS IN PREOPERATIVE SURGICAL PATIENT UNDERGOING MAJOR ABDOMINAL SURGERIES AND ITS RELATION TO POSTOPERATIVE OUTCOME
}

\author{
Rakesh Roshan¹, Ranjit Kumar Deka², Kaushik Vora ${ }^{3}$, Karthik H. K, Aditi Komandur ${ }^{5}$ \\ 1 Postgraduate Student, Department of General Surgery, Gauhati Medical College and Hospital (GMCH), Assam. \\ 2 Professor, Department of General Surgery, Gauhati Medical College and Hospital (GMCH), Assam. \\ 3Postgraduate Student, Department of General Surgery, Gauhati Medical College and Hospital (GMCH), Assam. \\ 4 Postgraduate Student, Department of General Surgery, Gauhati Medical College and Hospital (GMCH), Assam. \\ ${ }^{5}$ Postgraduate Student, Department of General Surgery, Gauhati Medical College and Hospital (GMCH) Assam.
}

\section{ABSTRACT}

\section{BACKGROUND}

Abdominal surgery represents a premeditated trauma, which leads to nutritional depletion and its possible related adverse outcomes, especially in malnourished pre-operative patients. Hence, the aim of the study was to assess nutritional status of a cohort of preoperative patients undergoing major gastrointestinal surgery and its relation to post-operative outcome using different nutritional indices.

\section{MATERIALS AND METHODS}

The present study was a prospective observational study. The study group consisted of total of 139 patients undergoing elective abdominal surgeries in the Department of Surgery in Guwahati Medical College and Hospital between 1st July 2016 and $30^{\text {th }}$ June 2017. Nutritional status of all patients was assessed preoperatively with the help of nutritional tools such as PG-SGA, NRI, Serum Albumin, NRS 2002 and MUST. Patients were observed in the post-operative period for specific complications until the period of discharge (By one of the authors who was unaware of the pre-operative nutritional status). To assess the efficacy of the nutritional indices in predicting post-operative complications $\mathrm{p}$ value, chi-square, odds ratio, sensitivity, specificity, positive predictive value and negative predictive value were calculated wherever applicable.

Study Design- Prospective observational study.

\section{RESULTS}

Out of the 139 patients studied, 6 patients died in early post-operative period due to various reasons. The remaining 133 patients were analysed out of which $49.6 \%, 53.8 \%, 36 \%, 81.9 \%$ and $50.4 \%$ were found to be malnourished according to PG-SGA, NRI, Serum Albumin, NRS 2002 and MUST respectively. Out of 133 patients, 70 were found to be free of complication. All the tools showed positive correlation on comparing the preoperative nutritional status and post complication rate with a $\mathrm{p}$ value $<0.0001$ consistently. However, the odds ratio was 17.3, 9.1, 2.8, 87.5 and 15.5 in PG-SGA, NRI, Serum Albumin, NRS 2002 and MUST respectively.

\section{CONCLUSION}

Our study concluded that all of the screening tools accurately help in predicting the post-operative outcome, however, on taking parameters such as sensitivity, specificity and predictive values into account. PG-SGA was found to be superior compared to other screening tools.

\section{KEYWORDS}

Nutritional Assessment, MUST Tool, PG-SGA, Post-Operative Complications.

HOW TO CITE THIS ARTICLE: Roshan R, Deka RK, Vora K, et al. Assessment of nutrition status in preoperative surgical patient undergoing major abdominal surgeries and its relation to postoperative outcome. J. Evolution Med. Dent. Sci. 2018;7(12):14471453, DOI: $10.14260 /$ jemds/2018/329

\section{BACKGROUND}

Malnutrition is prevalent in hospitalised patients with estimated prevalence of $20 \%-60 \%$ according to studies.1,2,3 Malnutrition is complex interplay between underlying diseases, disease related metabolic alterations and reduced availability and absorption of energy requirements.

'Financial or Other Competing Interest': None.

Submission 06-02-2018, Peer Review 03-03-2018,

Acceptance 08-03-2018, Published 19-03-2018.

Corresponding Author:

Dr. Rakesh Roshan,

S/o. Umesh Mandal,

Vill: Nandagram (Oosri),

P. O. Gogri Jamalpur,

Jamalpur-851203, Dist-Khagaria, Bihar

E-mail: drrakeshroshan007@gmail.com

DOI: $10.14260 /$ jemds $/ 2018 / 329$

\section{(c) $($ ) $(-)$}

Malnutrition causes a number of negative consequences such as increased susceptibility of infections, poor wound healing, increased frequency of decubitus ulcer overgrowth of bacteria in gastrointestinal tract. 4,5

The rate of development of post-operative malnutrition depends upon pre-existing nutritional status, nature and complexity of surgical procedure and degree of hypermetabolism. Hence, a previously malnourished patient is more expected to have post-operative complications.

Long-standing protein-calorie malnutrition is easy to recognise. Short-term undernutrition, although less easily recognised, frequently occurs in association with critical illness, major trauma, burns or surgery, and impacts on patient recovery. Hence, assessment of nutritional status is required in pre-operative period and proper intervention may be done to improve post-operative surgical outcome. 
The absence of a single gold standard objective measure has led investigators to develop various nutritional indices that can be used to stratify patients at increased risk for poor outcomes. These prognostic indices include the Nutritional Risk Index (NRI) and the Maastricht Index (MI), which are based on mathematical equations and MUST Tool, NRS 2002. The Subjective Global Assessment (SGA), Patient Generated Subjective Global Assessment (PG-SGA) and Mini Nutritional Assessment (MNA), which are based on clinical and subjective assessment.6,7,8

\section{Aims and Objectives}

To assess the nutritional status of preoperative patients undergoing major gastrointestinal surgery and its correlation with postoperative morbidity and mortality.

\section{MATERIALS AND METHODS Study Design}

The present study was a prospective observational study. The study group consisted of total of 139 patients undergoing elective abdominal surgeries in the Department of Surgery in Guwahati Medical College and Hospital between $1^{\text {st } J u l y ~} 2016$ and $30^{\text {th }}$ June 2017.

Institutional approval of the study protocol was obtained and the patients included in the study were informed about the proposed study and informed consent was obtained from each patient.

\section{Inclusion Criteria}

Patients admitted for major abdominal surgeries (including oncologic resection for gastrointestinal malignancy, solid organ resection, stoma closure with resection and anastomosis by laparotomies and having a duration of surgery lasting $>2 \mathrm{hrs}$.) under the Department of Surgery in GMCH, Guwahati. Both males and females $>12$ years were included in the study.

\section{Exclusion Criteria}

Patients who had undergone preoperative nutritional support, expected to die within six months due to their primary disease.

\section{Method of Collection of Data}

Details of cases were recorded including history and clinical examination (clinical deficiency if any noted). Anthropometric measurements such as height, weight, triceps-fold thickness and mid-upper arm circumference were recorded.

PG-SGA (patient generated subjective global assessment), MUST (Malnutrition Universal Screening Tool), NRI (Nutritional Risk Index) and NRS (Nutritional Risk Screening) scoring system and serum albumin were used.

PG-SGA ${ }^{8}$ - It was designed so that the components of the medical history can be completed by the patient using a check box format. The physical examination is then performed. The scored PG-SGA is a concept that incorporates a numerical score as well as providing a global rating of well-nourished, moderately or suspected of being malnourished or severely malnourished. For each component of the scored PG-SGA, points $(0-4)$ are awarded depending on the impact of the symptom on nutritional status. A total score is then summed and this provides a guideline as to the level of nutrition intervention required as well as facilitating quantitative outcome data collection. The scored PG-SGA is a continuous measure. The higher the score, the greater the risk for malnutrition. A score 9 indicates a critical need for nutrition intervention. The scored PG-SGA has been accepted by the Oncology Nutrition Dietetic Practice Group of the American Dietetic Association as the standard for nutrition assessment for patients with cancer. 9

\section{NRI}

The nutritional risk index is an example of one published method for determining the degree of malnutrition present in the preoperative patient. NRI is not a tool for tracking the adequacy of nutritional support, since supplemental nutrition often fails to improve serum albumin levels-

- $\quad \mathrm{NRI}=[1.489 \times \mathrm{Alb}]+41.7 \times$ [actual wt $(\mathrm{kg}) /$ usual wt $(\mathrm{kg})]$

- $\quad$ NRI defines the following set of scores for respective nutritional status- Well-nourished $>100$, Mild malnutrition 97.5 - 100, Moderate malnutrition 83.5 97.5 and Severe Malnutrition $<83.5$.

\section{Must Tool ('Malnutrition Universal Screening Tool') ${ }^{\mathbf{1 0}}$}

'MUST' is a five-step screening tool to identify adults who are malnourished, at risk of malnutrition (undernutrition) or obese. It also includes management guidelines, which can be used to develop a care plan. It incorporates the BMI score, weight loss score and acute illness score to divide patients into 3 categories of low risk, mild risk and high risk.

\section{Nutrition Risk Screening- 2002 (NRS Score) ${ }^{11}$}

The purpose of the NRS 2002 system is to detect the presence of undernutrition and the risk of developing undernutrition in the hospital setting. It contains the nutritional components of MUST and in addition a grading of severity of disease as a reflection of increased nutritional requirements.

Published in 2003 by the Danish Association of Parenteral and Enteral Nutrition, NRS 2002 is an ESPEN-recommended tool for inpatient nutrition risk screening which includes three main components: (I) Score of impaired nutritional status (0 to 3), (II) Score of disease severity (0 to 3) and (III) Age score where one extra point will be assigned to this category for patients aged 70 years or older. The total score is 0 to 7 points.

In our Study Classification of Malnutrition according to Severity was as follows

\begin{tabular}{|c|c|c|c|c|}
\hline $\begin{array}{c}\text { Assessment } \\
\text { Tools }\end{array}$ & Well & Mild & Moderate & Severe \\
\hline $\begin{array}{c}\text { PG-SGA } \\
\text { Score }\end{array}$ & 0 to 1 & 2 to 3 & 4 to 8 & $\begin{array}{c}\text { More than or } \\
\text { equal to } 9\end{array}$ \\
\hline NRI Index & $>=100$ & $\begin{array}{c}>=97.5- \\
<100\end{array}$ & $\begin{array}{c}>=83.5- \\
<97.5\end{array}$ & $<=83.5$ \\
\hline Albumin & $\begin{array}{c}>4 \\
\text { gm } / \mathrm{dL}\end{array}$ & $\begin{array}{c}>3.5-4 \\
\text { gm/dL }\end{array}$ & $\begin{array}{c}>3-3.5 \\
\text { gm/dL }\end{array}$ & $<=3 \mathrm{gm} / \mathrm{dL}$ \\
\hline Must & 0 & 1 & 2 \\
\hline NRS 2002 & \multicolumn{5}{|c|}{$0-2$} & Table 1 \\
\hline \multicolumn{5}{|c|}{} \\
\hline
\end{tabular}

Post-operative variables chosen for analysis were return of bowel function, surgical site infections, ICU care, ventilator support, sepsis, renal complications, pulmonary 
complications, cardiac complications, gastrointestinal complications, wound dehiscence, deep site infection, DVT, post-op nutritional support besides any other untoward outcome noticed.

\section{Statistical Analysis}

Statistical analysis was done using rates, ratios and proportions. Chi-square test was used to test the significance and $\mathrm{P}$ value $<0.05$ was considered statistically significant. Microsoft Excel 2007 was used for tabulation of data. Tabulated data were presented using Pie diagram, Bar diagram and graphs.

\section{RESULTS}

Patients admitted for major gastrointestinal surgery after proper diagnosis from July 2016 to June 2017 were assessed for nutritional status. Total of 139 patients were included in the study, out of which 6 patients died in early post-operative period. The cause of death was found to be myocardial infarction in 3 patients, MODS in 2 patients and intraabdominal haemorrhage in 1 patient. The remaining 133 patients were analysed for post-operative complications after proper assessment of nutritional status using clinical history, physical examination, lab analysis and nutritional assessment tools such as PG-SGA, NRI, Serum albumin, NRS 2002 and MUST. Further, the patients were classified according to the severity of nutritional status with help of nutritional screening tools.

Out of the 139 patients, 8 patients were found to have clinical evidence of nutritional deficiencies such as atrophic glossitis in Vitamin B12 deficiency, scaly skin in Vitamin A deficiency and increased risk of bleeding as occurs with Vitamin K deficiency.

\begin{tabular}{|c|c|c|c|}
\hline $\begin{array}{c}\text { Organ System } \\
\text { Involved }\end{array}$ & $\begin{array}{c}\text { Number of } \\
\text { Benign }\end{array}$ & $\begin{array}{c}\text { No. of } \\
\text { Malignant }\end{array}$ & $\begin{array}{c}\text { Total } \\
\text { Number }\end{array}$ \\
\hline Oesophagus & 0 & 1 & 1 \\
\hline Gastric & 8 & 6 & 14 \\
\hline Hepatobiliary & 45 & 9 & 54 \\
\hline Pancreas & 15 & 10 & 25 \\
\hline Spleen & 5 & 0 & 5 \\
\hline Small intestine & 10 & 3 & 13 \\
\hline Large intestine & 11 & 12 & 23 \\
\hline Ovary & 2 & 0 & 2 \\
\hline Others & 2 & 0 & 2 \\
\hline & 98 & 41 & 139 \\
\hline
\end{tabular}

Table 2. Showing distribution of Patients according to Benign or Malignant Involvement of Organ System

\begin{tabular}{|c|c|c|}
\hline Parameter & Mean & Range \\
\hline Age & 39.4 & $17-65$ \\
\hline Sex & M 58, F 75 & \\
\hline BMI & 21.27 & $16.38-26.7$ \\
\hline Albumin & 3.8 & $2.7-4.5$ \\
\hline Haemoglobin & 11.4 & $8.2-14$ \\
\hline Skin fold thickness & $13 \mathrm{~mm}$ & \\
\hline MAMC & $21 \mathrm{~cm}$ & \\
\hline \multicolumn{3}{|c|}{ Table 3. Patient Demographics } \\
\hline
\end{tabular}

Analysis of Malnutrition according to different Assessment Tools

The nutritional status of the patient was assessed with the help of serum albumin levels, PG-SGA, NRI, NRS 2002 and MUST.

\section{Classification of Malnutrition}

The assessment tools enable us to classify the patients into various categories. PG-SGA, NRI and Albumin help us classify patients into well, mild, moderate and severely malnourished categories, whereas NRS 2002 have two categories well and malnourished group and MUST tool have three categories well, at mild risk and at high risk.

The number of patients falling in each of the groups according to the different assessment tools has been shown in the graph below.

Chart showing Patient Distribution according to Nutritional Status

\begin{tabular}{|c|c|c|c|c|c|c|c|c|c|}
\hline \multirow[b]{2}{*}{ NAT } & \multicolumn{2}{|c|}{ Well } & \multicolumn{2}{|c|}{ Mild } & \multicolumn{2}{|c|}{ Moderate } & \multicolumn{2}{|c|}{ Severe } & \multirow[b]{2}{*}{ 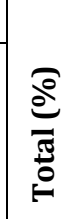 } \\
\hline & 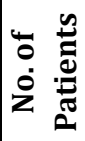 & $\stackrel{̊}{\Xi}$ & 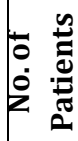 & $\stackrel{0}{\Xi}$ & 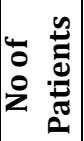 & $\begin{array}{l}\delta^{\circ} \\
\Xi\end{array}$ & 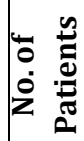 & $\stackrel{0}{\Xi}$ & \\
\hline PG-SGA & 66 & 49.6 & 23 & 17.2 & 28 & 21.05 & 16 & 12.03 & $\begin{array}{c}133 \\
(100)\end{array}$ \\
\hline NRI & 71 & \begin{tabular}{|c|}
53.3 \\
8 \\
\end{tabular} & 18 & 13.5 & 32 & 24.06 & 12 & 9 & \begin{tabular}{|c|}
133 \\
$(100)$ \\
\end{tabular} \\
\hline MUST & 67 & $\begin{array}{c}50.3 \\
7\end{array}$ & & 30 & & 22.55 & 36 & 27.06 & $\begin{array}{c}133 \\
(100)\end{array}$ \\
\hline \begin{tabular}{|c|} 
Serum \\
Albumin
\end{tabular} & 48 & 36 & 50 & 37.5 & 16 & 12.03 & 19 & 14.3 & $\begin{array}{c}133 \\
(100)\end{array}$ \\
\hline $\begin{array}{c}\text { NRS } \\
2002\end{array}$ & & 109 & & 81.9 & & 24 & & 18.04 & $\begin{array}{c}133 \\
(100)\end{array}$ \\
\hline
\end{tabular}

Distribution of Patients according to Specific Complications

The complications were divided into superficial skin infection, pulmonary, renal, cardiac, sepsis, wound dehiscence, deep site infection and post-operative ventilator support.

\section{The distribution of these has been Outlined in the Table}

\begin{tabular}{|c|c|}
\hline Number of patients with complication & 63 \\
\hline Number of patients with no complication & 70 \\
\hline Total Number of Patients with & \\
\hline Superficial skin infection & 36 \\
\hline Pulmonary & 34 \\
\hline Cardiac & 4 \\
\hline Ventilator support & 23 \\
\hline Renal & 15 \\
\hline Gastrointestinal & 22 \\
\hline DVT & 1 \\
\hline Sepsis & 5 \\
\hline Wound dehiscence & 6 \\
\hline Deep site infection & 6 \\
\hline
\end{tabular}


Nutritional Status and its Relation to Number of Complications

All of the patients were classified into severity indices according to each of the assessment tools and the complications were recorded against each class. According to PG-SGA, 83 percent of the patients in the well-nourished category had no complications.
100 percent of the patients who were severely malnourished had complications, while more than 50 percent of total had 4 or more complications. This aided a Chi-square test of 101.29 .

With 15-Degree of Freedom and a P value $<0.0001$. Chart is represented below

\begin{tabular}{|c|c|c|c|c|c|c|c|c|c|}
\hline NAT & $\begin{array}{c}\text { Total } \\
\text { Patients }\end{array}$ & $\begin{array}{c}\text { Without } \\
\text { Complication }\end{array}$ & One & Two & Three & Four & Five & $\begin{array}{c}\text { Total Patients } \\
\text { having } \\
\text { Complications }\end{array}$ & $\begin{array}{c}\text { \%ccording to } \\
\text { Respective } \\
\text { Groups }\end{array}$ \\
\hline Well & 66 & 55 & 5 & 4 & 2 & 0 & 0 & 11 & 16.6 \\
\hline Mild & 33 & 23 & 2 & 3 & 4 & 1 & 0 & 10 & 30 \\
\hline Moderate & 28 & 2 & 10 & 6 & 5 & 4 & 1 & 14 & 50 \\
\hline Severe & 16 & 0 & 3 & 0 & 4 & 9 & 0 & 16 & $100 \%$ \\
\hline
\end{tabular}

\section{NRI- Nutritional Status and Number of Complications}

The severity of the complication was analysed for all the 4 groups of patients. A definite correlation was found, in which the severely malnourished patients exhibited higher incidence of having complications. Maximum number of patients falling in the well and mildly nourished categories were found to have no complications. The well-nourished candidates showed merely 23 percent of patients having complications. Only 2 of the 18 patients who were mildly malnourished had more than 2 complications. The moderately nourished patients showed a scattered distribution of complication rate with $10 \%$ having no complications. $40 \%$ of the patients had one complication and the rest having 2 or more complications with an uneven distribution of number.

Distribution of Patients according to (Severity) Number of Complications (NRI)

\begin{tabular}{|c|c|c|c|c|c|c|c|c|c|}
\hline NAT & $\begin{array}{c}\text { Without } \\
\text { Compl }\end{array}$ & $\begin{array}{c}\text { No. of } \\
\text { Patients } \\
\text { with One } \\
\text { Compl }\end{array}$ & $\begin{array}{c}\text { No. of } \\
\text { Patients } \\
\text { with Two } \\
\text { Compl }\end{array}$ & $\begin{array}{c}\text { No. of } \\
\text { Patients } \\
\text { with } \\
\text { Three } \\
\text { Compl }\end{array}$ & $\begin{array}{c}\text { No. of } \\
\text { Patients } \\
\text { with Four } \\
\text { Compl }\end{array}$ & $\begin{array}{c}\text { No. of } \\
\text { Patients } \\
\text { with Five } \\
\text { Compl }\end{array}$ & $\begin{array}{c}\text { Total } \\
\text { Number of } \\
\text { Patients in } \\
\text { Each Group }\end{array}$ & $\begin{array}{c}\text { Total Number } \\
\text { of Patients } \\
\text { with Compl }\end{array}$ & $\begin{array}{c}\text { \% According } \\
\text { to Respect } \\
\text { Groups }\end{array}$ \\
\hline Well & 54 & 5 & 6 & 5 & 1 & 0 & 71 & 17 & 23.94 \\
\hline Mild & 13 & 2 & 1 & 2 & 0 & 0 & 18 & 5 & 27.7 \\
\hline Moderate & 3 & 12 & 6 & 4 & 6 & 1 & 32 & 29 & 90.62 \\
\hline Severe & 0 & 1 & 0 & 4 & 7 & 0 & 12 & 12 & 100 \\
\hline Total & 70 & & & & & & 133 & 63 & \\
\hline
\end{tabular}

Chi-square test- 90.08, P value $<0.0001$, Degree of freedom- 15

Albumin- Nutritional Status and Number of Complications

More than 70 percent of the well patients showed no complications. 23 percent of the patients had 2 or more complications in this group.

A similar picture was seen in the mild group with more than 86 percent of patients having 0 - 1 complications. More than 70 percent of moderately malnourished patients had 2 or more complications.

All the severely malnourished patients had complications with nearly 50 percent having 4 or more complications.

Distribution of Patients according to (Severity) Number of Complications (Albumin)

\begin{tabular}{|c|c|c|c|c|c|c|c|c|c|}
\hline NAT & $\begin{array}{c}\text { Without } \\
\text { Compl }\end{array}$ & $\begin{array}{c}\text { No. of } \\
\text { Patients } \\
\text { with One } \\
\text { Compl }\end{array}$ & $\begin{array}{c}\text { No. of } \\
\text { Patients } \\
\text { with Two } \\
\text { Compl }\end{array}$ & $\begin{array}{c}\text { No. of } \\
\text { Patients } \\
\text { with Three } \\
\text { Compl }\end{array}$ & $\begin{array}{c}\text { No. of } \\
\text { Patients } \\
\text { with Four } \\
\text { Compl }\end{array}$ & $\begin{array}{c}\text { No. of } \\
\text { Patients } \\
\text { with Five } \\
\text { Compl }\end{array}$ & $\begin{array}{c}\text { Total Number } \\
\text { of Patients in } \\
\text { Each Group }\end{array}$ & $\begin{array}{c}\text { Total Number } \\
\text { of Patients } \\
\text { with } \\
\text { Compl }\end{array}$ & $\begin{array}{c}\text { \% } \\
\text { According } \\
\text { to Respect } \\
\text { Groups }\end{array}$ \\
\hline Well & 33 & 4 & 5 & 5 & 1 & 0 & 48 & 15 & 31.25 \\
\hline Mild & 36 & 7 & 5 & 2 & 0 & 0 & 50 & 14 & 28 \\
\hline Moderate & 1 & 4 & 2 & 4 & 4 & 1 & 16 & 15 & 93.75 \\
\hline Severe & 0 & 5 & 1 & 4 & 9 & 0 & 19 & 19 & 100 \\
\hline Total & $\mathbf{7 0}$ & \multicolumn{7}{|r|}{} &
\end{tabular}

Chi-square test- 70.12, P value $<0.0001$, Degree of freedom- 15 
NRS 2002- Nutritional Status and Number of Complications

Distribution of Patients according to (Severity) Number of Complications (NRS 2002).

\begin{tabular}{|c|c|c|c|c|c|c|c|c|c|}
\hline NAT & $\begin{array}{c}\text { Without } \\
\text { Compl }\end{array}$ & $\begin{array}{c}\text { No. of } \\
\text { Patients } \\
\text { with One } \\
\text { Compl }\end{array}$ & $\begin{array}{c}\text { No. of } \\
\text { Patients } \\
\text { with Two } \\
\text { Compl }\end{array}$ & \begin{tabular}{|c|} 
No. of \\
Patients with \\
Three Compl
\end{tabular} & $\begin{array}{c}\text { No. of } \\
\text { Patients } \\
\text { with Four } \\
\text { Compl }\end{array}$ & $\begin{array}{c}\text { No. of } \\
\text { Patients } \\
\text { with Five } \\
\text { Compl }\end{array}$ & \begin{tabular}{|} 
Total Number \\
of Patients in \\
Each Group
\end{tabular} & $\begin{array}{c}\text { Total } \\
\text { Number of } \\
\text { Patients } \\
\text { with Compl }\end{array}$ & $\begin{array}{c}\% \\
\text { According to } \\
\text { Respect } \\
\text { Groups }\end{array}$ \\
\hline Well & 70 & 15 & 11 & 9 & 3 & 1 & 109 & 39 & 35.77 \\
\hline At Risk & 0 & 5 & 2 & 6 & 11 & 0 & 24 & 24 & 100 \\
\hline Total & 70 & & & & & & 133 & 63 & \\
\hline
\end{tabular}

Chi-square- 55.9, Degree of freedom- 5 , P value $<0.0001$

\begin{tabular}{|c|c|c|c|c|c|c|c|c|c|}
\hline NAT & $\begin{array}{c}\text { Without } \\
\text { Compl }\end{array}$ & \begin{tabular}{|c|} 
No. of \\
Patients \\
with One \\
Compl
\end{tabular} & $\begin{array}{c}\text { No. of } \\
\text { Patients } \\
\text { with Two } \\
\text { Compl }\end{array}$ & $\begin{array}{c}\text { No. of } \\
\text { Patients } \\
\text { with Three } \\
\text { Compl }\end{array}$ & $\begin{array}{c}\text { No. of } \\
\text { Patients } \\
\text { with Four } \\
\text { Compl }\end{array}$ & $\begin{array}{c}\text { No. of } \\
\text { Patients } \\
\text { with Five } \\
\text { Compl }\end{array}$ & \begin{tabular}{|c|} 
Total \\
Number of \\
Patients in \\
Each Group
\end{tabular} & $\begin{array}{c}\text { Total Number } \\
\text { of Patients } \\
\text { with Compl }\end{array}$ & $\begin{array}{c}\text { \% According } \\
\text { to } \\
\text { Respect } \\
\text { Groups }\end{array}$ \\
\hline Well & 55 & 4 & 6 & 2 & 0 & 0 & 67 & 12 & 17.91 \\
\hline $\begin{array}{l}\text { Medium } \\
\text { Risk }\end{array}$ & 14 & 8 & 2 & 4 & 1 & 1 & 30 & 16 & 53.33 \\
\hline High Risk & I & 8 & 5 & 9 & 13 & 0 & 36 & 35 & 97.22 \\
\hline Total & 70 & & & & & & 133 & 63 & \\
\hline
\end{tabular}

Chi-square- 52.226, P value $<0.0001$, Degree of freedom- 10

The high risk group showed nearly 80 percent of patients to have more than 2 complications compared to the medium risk which showed nearly only 30 percent to have more than 2 complications.

\section{MUST}

55 out of 67 patients who were in the low risk category had no complications. The medium risk category showed marginally higher complication rates than without complication. The high risk group had just 1 patient out of 36 with no complications.

Distribution of Patients according to (Severity) Number of Complications (MUST)

\begin{tabular}{|c|c|c|c|c|c|c|c|c|c|}
\hline NAT & $\begin{array}{c}\text { Without } \\
\text { Compl }\end{array}$ & $\begin{array}{c}\text { No. of } \\
\text { Patients } \\
\text { with One } \\
\text { Compl }\end{array}$ & $\begin{array}{c}\text { No. of } \\
\text { Patients } \\
\text { with Two } \\
\text { Compl }\end{array}$ & \begin{tabular}{|c|} 
No. of \\
Patients \\
with Three \\
Compl
\end{tabular} & $\begin{array}{c}\text { No. of } \\
\text { Patients } \\
\text { with Four } \\
\text { Compl }\end{array}$ & \begin{tabular}{|c|} 
No. of \\
Patients \\
with Five \\
Compl
\end{tabular} & \begin{tabular}{|c|} 
Total \\
Number of \\
Patients in \\
Each Group
\end{tabular} & $\begin{array}{c}\text { Total Number } \\
\text { of Patients with } \\
\text { Compl }\end{array}$ & $\begin{array}{c}\text { \% According } \\
\text { to } \\
\text { Respect } \\
\text { Groups }\end{array}$ \\
\hline Well & 55 & 4 & 6 & 2 & 0 & 0 & 67 & 12 & 17.91 \\
\hline $\begin{array}{l}\text { Medium } \\
\text { Risk }\end{array}$ & 14 & 8 & 2 & 4 & 1 & 1 & 30 & 16 & 53.33 \\
\hline High Risk & I & 8 & 5 & 9 & 13 & 0 & 36 & 35 & 97.22 \\
\hline Total & 70 & & & & & & 133 & 63 & \\
\hline
\end{tabular}

Chi-square 52.226, P value $<0.0001$, Degree of freedom- 10

The high risk group showed nearly 80 percent of patients to have more than 2 complications compared to the medium risk which showed nearly only 30 percent to have more than 2 complications.

In the present study, all nutrition assessment tools could reliably predict the nutrition status and risk of getting postoperative complications.

\begin{tabular}{|c|c|c|c|c|c|c|c|}
\hline Tools & P value & Chi-Square Test & Odds Ratio & Sensitivity \% & Specificity \% & PPV \% & NPV \% \\
\hline PG-SGA & $<0.0001$ & 30.41 & 17.33 & 78.57 & 82 & 83.4 & 77 \\
\hline NRI & $<0.0001$ & 55.74 & 9.132 & 77 & 73 & 76 & 74 \\
\hline Albumin & $<0.0001$ & 25.82 & 2.85 & 47 & 76.19 & 68.75 & 56.47 \\
\hline NRS 2002 & $<0.0001$ & 33.7 & 87.54 & 100 & 38 & 60 & 1 \\
\hline MUST & $<0.0001$ & 29.97 & 15.583 & 78 & 80 & 82. & 77.77 \\
\hline
\end{tabular}


DISCUSSION

\begin{tabular}{|c|c|c|c|}
\hline \multicolumn{4}{|c|}{ Present Study } \\
\hline Total Number & \multicolumn{2}{|c|}{ Complications } & P value \\
\hline & Yes & No & \\
\hline 109 & 39 & 70 & $<0.0001$ \\
\hline 24 & 0 & 24 & \\
\hline 48 & 15 & 33 & \\
\hline 66 & 29 & 37 & $<0.0001$ \\
\hline 19 & 19 & 0 & \\
\hline
\end{tabular}

\section{Vanina Cor Deiro De Souza et al ${ }^{12}$}

Studied relationship between nutritional status and immediate complications in patients undergoing colorectal surgeries evaluated 31 patients according to SGA, NRS 2002 and serum albumin and assess the immediate post-operative complications.

\begin{tabular}{|c|c|c|c|c|c|}
\hline \multicolumn{2}{|c|}{} & Total No. & Complications & P value \\
\hline NRS 2002 & & & Yes & No & \\
\hline & Without risk & 13 & 5 & 8 & 1.000 \\
\hline & With risk & 18 & 7 & 11 & \\
\hline $\begin{array}{c}\text { Serum } \\
\text { Albumin }\end{array}$ & & & & & \\
\hline & Normal & 21 & 7 & 14 & 0.256 \\
\hline & $\begin{array}{c}\text { Mild-to- } \\
\text { Moderate }\end{array}$ & 7 & 4 & 3 & \\
\hline \multicolumn{7}{|c|}{ Severe } & 1 & 1 & 0 & \\
\hline \multicolumn{7}{|c|}{ Vanina Cor Deiro De Souza et al } \\
\hline
\end{tabular}

In above study by Vanina et al, all assessment tools although predict increased risk of complication but all seems to be statistically insignificant.

On studying NRS 2002 and serum albumin as predictors for complications in relation to nutritional status, we obtained a statistically significant value of $<0.0001$ in either case.

\section{Mehmet A Kuzu MD et al13}

Studied nutritional risk assessment in predicting postoperative outcomes undergoing major elective gastrointestinal surgeries of 460 patients using NRI, Maastricht index (MI), SGA concluded that post-operative complication was significantly higher in malnourished patients in all nutritional indices used. The odds ratio for morbidity between well-nourished and malnourished patients was 3.09 (3.09 [95\% confidence interval (CI), 1.964.88), 3.47 (95\% CI, 2.12-5.68), 2.30 (95\% CI, 1.43-3.71) and 2.81 (95\% CI, 0.79-9.95) for the SGA, NRI, MI and MNA, respectively. All indices except the MNA were significantly predictive for morbidity. The odds ratios were not statistically different among the indices. In their study assessment with NRI showed the following results with ' $p$ ' value $<0.0001$

\begin{tabular}{|c|c|c|c|c|}
\hline & \multicolumn{2}{|c|}{$\begin{array}{c}\text { Mehmet A. } \\
\text { Kuzu MD, et al }\end{array}$} & \multicolumn{2}{c|}{$\begin{array}{c}\text { Present } \\
\text { Study }\end{array}$} \\
\hline NRI & $\begin{array}{c}\text { No Compli- } \\
\text { cation }\end{array}$ & $\begin{array}{c}\text { Compli- } \\
\text { cation }\end{array}$ & $\begin{array}{c}\text { No } \\
\text { Complication }\end{array}$ & $\begin{array}{c}\text { Compli- } \\
\text { cation }\end{array}$ \\
\hline Well-Nourished & 144 & 24 & 54 & 17 \\
\hline Malnourished & 185 & 107 & 16 & 46 \\
\hline
\end{tabular}

In our study, we had a similar finding with a p value < 0.0001 on using NRI as an assessment tool.

\section{MUST6 / Mariana Raslan RD et al}

Conducted a study of comparison of nutritional screening tools for predicting clinical outcomes in hospitalised patients. They assessed 705 patients with the help of MUST tool and the following results were obtained. A $p$ value of $<0.0001$ was obtained.

\begin{tabular}{|c|c|c|c|c|}
\hline & \multicolumn{2}{|c|}{ Mariana Raslan RD, et al } & \multicolumn{2}{c|}{ Present Study } \\
\hline MUST & $\begin{array}{c}\text { No } \\
\text { Complications }\end{array}$ & Complications & $\begin{array}{c}\text { No } \\
\text { Complications }\end{array}$ & Complications \\
\hline $\begin{array}{c}\text { No } \\
\text { risk }\end{array}$ & 375 & 51 & 55 & 12 \\
\hline $\begin{array}{c}\text { At } \\
\text { risk }\end{array}$ & 217 & 62 & 15 & 51 \\
\hline
\end{tabular}

$P$ value $<0.0001, P$ value $<0.0001$

In our study of 133 patients, the below results were obtained with the same $p$ value of $<0.0001$ with a concurring result as above.

\section{CONCLUSION}

We conducted a prospective, non-randomised, time bound study in Guwahati Medical College and Hospital from $1^{\text {st }}$ July 2016 to 30th June 2017. Our study included a total of 139 patients who underwent major gastrointestinal surgeries in the Department of General Surgery, GMCH. The aim of this study was to assess the nutritional status preoperatively of patients undergoing major gastrointestinal surgery and its relation to post-operative outcome.

We used various assessment tools such as PG-SGA, NRI, MUST, NRS 2002 and Albumin to assess the nutritional status preoperatively. $81.9 \%$ of patients were found to be well nourished according to NRS 2002, 53.3\% according to NRI, $50.3 \%$ according to MUST, $49.6 \%$ according to PG-SGA and $36 \%$ of patients according to Albumin were found to be well nourished. Rest of the patients fell into the malnourished category accordingly.

On observing all patients post-operatively, it was found that $53 \%$ of the patients had a complication free postoperative phase. The $47 \%$ of the patients having complications were analysed according to the nutritional status of the patients.

While the PG-SGA analysis showed $83.3 \%$ of the wellnourished patients to be complication free, the NRS 2002 showed a marked difference with $64.2 \%$ of adequately nourished patients to have complication free in postoperative period. This may be due to different parameters used in different assessment tools. In this context, PG-SGA appears to be more reliable in predicting post-operative outcome than NRS 2002. However, PG-SGA was more exhaustive and time consuming for assessment of nutritional status.

We also observed the incidence of specific complications according to the nutritional status and found a significant correlation for pulmonary complications, gastrointestinal complications, post-op ventilator support, sepsis and wound dehiscence. 
Thus, the present study demonstrates that there is a definite correlation between pre-operative nutritional status and post-operative outcome, morbidity and mortality.

Various studies have been conducted assessing the nutritional status with the help of different tools in combination. Patients having varying or specified preoperative diagnosis were studied and different postoperative variables were considered to predict relation between the assessment tools and postoperative outcome in relation to nutritional status of the patient. Overall, PG-SGA appeared to have better sensitivity, specificity, positive predictive value and negative predictive value.

All nutritional assessment tools seem to corroborate assessing nutritional status with post-operative outcome. Despite NRS 2002 having a $\mathrm{p}$ value of $<0.0001$ and a sensitivity of $100 \%$ it cannot be considered to be an ideal tool, because it divides patients into only 2 categories and hence is not able to provide us with an adequate assessment according to severity.

All the nutritional tools used weight loss (in last 1 to 6 months) as a common assessing factor, hence proving that it is one of the important determinants of outcomes in patients.

Malnutrition and starvation in surgical patients in combination with the disease processes itself grossly impairs the immune function. For a patient to cope with the surgical insult and post-operative hypermetabolic state an intact immunity and adequate nutritional reserve is necessary. In addition, the phase of postoperative starvation is highly dependent on body reserve. Hence, proper assessment of preoperative nutritional status is important to predict the postoperative outcome and complications in major gastrointestinal surgeries.

\section{REFERENCES}

[1] $\mathrm{Wu} \mathrm{GH}$, Liu ZH, Zheng LW, et al. Prevalence of malnutrition in general surgical patients: evaluation of nutritional status and prognosis. Zhonghua Wai Ke Za Zhi 2005;43(11):693-6.

[2] Kahokehr AA, Sammour T, Wang K, et al. Prevalence of malnutrition on admission to hospital - acute and elective general surgical patients. e-SPEN, the European e-Journal of Clinical Nutrition and Metabolism 2010;5(1):e21-e5. doi:10.1016/j.eclnm.2009.11.001.

[3] Chakravarty C, Hazarika B, Goswami L, et al. Prevalence of malnutrition in a tertiary care hospital in India. Indian J Crit Care Med 2013;17(3):170-3. doi:10.4103/0972-5229.117058.
[4] Mainous MR, Deitch EA. Nutrition and infection. Surg Clin North Am 1994;74(3):659-76.

[5] Elwyn DH, Bryan-Brown CW, Shoemaker WC. Nutritional aspects of body water dislocations in postoperative and depleted patients. Ann Surg 1975;182(1):76-85.

[6] Raslan M, Gonzalez MC, Dias MC, et al. Comparison of nutritional risk screening tools for predicting clinical outcomes in hospitalized patients. Nutrition 2010;26(7-8):721-6.

http://www.sciencedirect.com/science/article/pii/S0 899900709003037.

[7] Detsky AS, McLaughlin JR, Baker JP, et al. What is subjective global assessment of nutritional status? JPEN J Parenter Enteral Nutr 1987;11(1):8-13. doi:10.1186/1757-2215-1-5.

[8] Dos Santos AC, de Oliveira BRC, Queiroz RA, et al. Patient-generated subjective global assessment and classic anthropometry: comparison between the methods in detection of malnutrition among elderly with cancer. Nutr Hosp 2015;31(1):384-92. doi:10.3305/nh.2015.31.

[9] Kehlet H. Multimodal approach to control postoperative pathophysiology and rehabilitation. Br J Anaesth 1997;78(5):606-17. doi:10.1097/00132586199808000-00048.

[10] Kondrup J, Allison SP, Elia M, et al. Special article. ESPEN guidelines for nutrition screening 2002. Clin Nutr 2003;22(4):415-21. doi:10.1016/S02615614(03)00098-0.

[11] Kondrup J, Rasmussen HH, Hamberg O, et al. Nutritional risk screening (NRS 2002): a new method based on an analysis of controlled clinical trials. Clin Nutr 2003;22(3):321-36. doi:10.1016/S02615614(02)00214-5.

[12] De Souza VC, Dourado KF, Lima ALC, et al. Relationship between nutritional status and immediate complications in patients undergoing colorectal surgery. J Coloproctology 2013;33(2):83-91. doi:10.1016/j.jcol.2013.05.003.

[13] Kuzu MA, Terzioğlu H, Genç V, et al. Preoperative nutritional risk assessment in predicting postoperative outcome in patients undergoing major surgery. World J Surg 2006;30(3):378-90. doi:10.1007/s00268-005-01 